\title{
PROBLEMY WYKONAWCZE PRZY POSADZCE ŻYWICZNEJ W GALERII HANDLOWEJ
}

\author{
Norbert Dąbkowski ${ }^{\boxplus}$, Agnieszka Majstrowicz \\ Wydział Budownictwa i Inżynierii Środowiska, Szkoła Główna Gospodarstwa Wiejskiego w Warszawie, Warszawa
}

\begin{abstract}
STRESZCZENIE
W artykule przedstawiono problemy, jakie wystąpiły podczas wykończenia podłogi galerii handlowej w Warszawie. Przybliżono budowę dwóch zastosowanych posadzek żywicznych, fazy technologiczne wykonania tych posadzek, napotkane problemy z powierzchnią stropu, na którym miały być wykonane posadzki, wdrożony sposób naprawy oraz problemy w wykończeniu wierzchniej warstwy posadzki żywicznej (pęcherze powietrzne). Sformułowano możliwe przyczyny ich powstania.
\end{abstract}

Słowa kluczowe: posadzka żywiczna, podłoga, wykonanie

\section{WSTĘP}

Posadzka stanowi wierzchnią warstwę podłogi, jest jej wykończeniem. W zależności od funkcji pomieszczenia posadzka powinna spełniać odpowiednie wymagania użytkowe. Rozróżnia się wiele jej typów i rodzajów, biorąc pod uwagę, czy będzie to zewnętrzna warstwa pomieszczenia biurowego, usługowo-handlowego, przeznaczonego do rekreacji czy parkowania pojazdów (Karwacki, 2002; Chmielewska, 2007). Posadzka powierzchni parkingu powinna chronić zbrojenie zatopione $\mathrm{w}$ betonie przed wnikaniem wody oraz soli, które mogą wywołać niepożądane i niebezpieczne zjawisko korozji. Inną konieczną do spełnienia funkcją posadzki jest posiadanie właściwości przykrywania rys i spękań powstałych w płycie żelbetowej. Dodatkowo należy uwzględnić niezbędne wymagane właściwości mechaniczne, takie jak: odporność na ścieranie, odporność na zarysowania, odporność na warunki atmosferyczne, odporność na zmiany temperatury, odporność na opady, odporność na środki przeznaczone do chemicznego czyszczenia oraz sól drogową, odporność na płyny samochodowe, odporność na ruch i obciążenia użytkowe oraz spowodowane przez nie odkształcenia (Tejchman i Małasiewicz, 2006; Czarnecki, 2008).

Wykonanie posadzki stanowi istotną część budżetu inwestycji. Posadzka jest także jednym z najszybciej zużywających się elementów obiektu. Jej eksploatacja niezbędna do utrzymania właściwego stanu generuje koszty przez cały okres użytkowania. W przypadku jej remontu należy również zwrócić uwagę na koszty pośrednie, tj. wyłączenie powierzchni $\mathrm{z}$ eksploatacji na czas naprawy bądź wymiany posadzki.

$\varpi_{\text {norbert_dabkowski@sggw.pl }}$ 


\section{MATERIAt I METODY}

W centrum handlowo-usługowo-rozrywkowym w Warszawie zaprojektowano wiele rozwiązań posadzek żywicznych:

- posadzkę na bazie żywic epoksydowych lub poliuretanowych, antypoślizgową z posypką z piasku kwarcowego (oznaczenie R10);

- posadzkę ramp samochodowych na bazie żywic epoksydowych lub poliuretanowych, antypoślizgową (R12);

- posadzkę na bazie żywic epoksydowych lub poliuretanowych, antypoślizgową, przeznaczoną do pomieszczeń śmietników;

- posadzkę uszczelnioną, zmywalną, odporną na kwasy i oleje (warstwa antypyłowa), impregnowną preparatami na bazie żywicy akrylowej z domieszkami krzemianowymi, żywicami poliuretanowymi lub dyspersją wodną żywic epoksydowych;

- posadzkę na bazie żywic poliuretanowych odpornych na promienie UV, antypoślizgową, z membraną hydroizolacyjną (oznaczenie RM11);

- posadzkę na bazie żywic epoksydowych lub poliuretanowych na warstwie buforowej, antypoślizgową z posypką z piasku kwarcowego (oznaczenie RG10);

- posadzkę na bazie żywic, poliuretanowo-epoksydową, z membraną hydroizolacji, antypoślizgową (oznaczenie RM12).

Rodzaj zastosowanej żywicy zależał głównie od lokalizacji danej posadzki i projektowanych funkcji podczas eksploatacji.

Dla powierzchni parkingów zaprojektowano następujące rozwiązania:

- posadzka typu RG10 - zlokalizowana na parkingu podziemnym poziomu -2 , na płycie fundamentowej;

- posadzka typu R10 - lokalizowana na parkingu podziemnym poziomu -1 , na stropie;

- posadzka typu RM11 - planowana na parking otwarty kondygnacji +2 (zrezygnowano i zastapiono posadzką betonową);

- posadzka typu RM12 - planowana na rampę wjazdową $\mathrm{R} 7 \mathrm{z}$ poziomu 0 na dach (zrezygnowano i zastąpiono posadzką betonową).

\section{Posadzka typu RG10}

Posadzka na bazie żywic epoksydowych lub poliuretanowych na warstwie buforowej, antypoślizgowa (R10) z posypką z piasku kwarcowego pokrywa powierzchnię ponad $20000 \mathrm{~m}^{2}$ parkingu podziemnego. Jej grubość wynosi $1,8 \mathrm{~mm}$. Jest twardo-elastyczna. Ma fakturę antypoślizgową R10/R11. Wymagania jej stawiane to również przenoszenie zarysowań od obciążeń statycznych.

Układ warstw w posadzce typu RG10:

- I warstwa - grunt: powłoka epoksydowa to ekonomiczna w użyciu żywica złożona $\mathrm{z}$ dwóch składników; przeznaczona jest do gruntowania podłoży; ma słabą lepkością, bardzo dobrą przyczepność, jest łatwa w aplikacji oraz ma bardzo dużą zdolność penetracji podłoża; przyjęto dawkowanie $0,40-0,50 \mathrm{~kg} \cdot \mathrm{m}^{-2}$, następnie piasek kwarcowy o uziarnieniu $0,4-0,8 \mathrm{~mm}$ w ilości $0,8 \mathrm{~kg} \cdot \mathrm{m}^{-2}$;

- II warstwa zasadnicza: powłoka poliuretanowa to bezrozpuszczalnikowa, przenosząca zarysowania, twardo-elastyczna żywica przeznaczona do powierzchni narażonych na ruch kołowy; ma fakturę antypoślizgową; jest łatwa w aplikacji, wodoszczelna, charakteryzuje się dużą odpornością na ścieranie; przyjęto dawkowanie $0,50-0,60 \mathrm{~kg} \cdot \mathrm{m}^{-2}$;

- III warstwa buforowa - fakturowa: zasypka z piasku kwarcowego o uziarnieniu $0,4-0,8 \mathrm{~mm}$ w ilości $3,0 \mathrm{~kg} \cdot \mathrm{m}^{-2}$;

- IV warstwa - zamykająca: zaproponowano materię w kolorze określonym barwnikiem RAL 7032, która jest dwuskładnikową, twardo-elastyczną żywicą przeznaczoną jako powłoka zamykająca posadzkę żywiczną; jest odporna na ścieranie, ma dobre parametry wytrzymałości mechaniczne oraz chemiczne; ma dużą siłę krycia, a jej właściwości gwarantują połysk wykończenia; stanowi warstwę ochronną przez wnikaniem wody oraz substancji chemicznych; zaleca się dawkowanie $0,60-0,70 \mathrm{~kg} \cdot \mathrm{m}^{-2}$.

\section{Posadzka typu R10}

Wykonana na bazie żywic epoksydowych lub poliuretanowych na warstwie buforowej, antypoślizgowa (R10) z posypką z piasku kwarcowego o docelowej grubości $2,5 \mathrm{~mm}$. Tak, jak poprzedni system, przykrywa on powierzchnię ponad 2 ha. Posadzka przenosi 
zarysowania od obciążeń statycznych, co jest ważne przy stosowaniu jej na stropie.

Układ warstw w posadzce typu R10:

- I warstwa - grunt: jak w posadzce typu RG10 jest to powłoka epoksydowa; przyjęto także takie samo dawkowanie materiału, tj. $0,40-0,50 \mathrm{~kg} \cdot \mathrm{m}^{-2}$, następnie piasek kwarcowy o uziarnieniu $0,4-0,8 \mathrm{~mm}$ w ilości $0,8 \mathrm{~kg} \cdot \mathrm{m}^{-2}$;

- II warstwa zasadnicza: powłoka poliuretanowa w zwiększonym niż na poziomie -1 dawkowaniu: $0,90-1,00 \mathrm{~kg} \cdot \mathrm{m}^{-2}$;

- III warstwa buforowo-fakturowa: zasypka z piasku kwarcowego o uziarnieniu $0,4-0,8 \mathrm{~mm}$ w ilości $3,0 \mathrm{~kg} \cdot \mathrm{m}^{-2}$

- IV warstwa zamykająca: przyjęto materiał o kolorze według barwnika RAL 7032, w dawkowaniu $0,60-0,70 \mathrm{~kg} \cdot \mathrm{m}^{-2}$.

Oba systemy maja praktycznie identyczną budowę. Różnice pojawiają się przy dawkowaniu drugiej warstwy, co jest spowodowane wymagana grubszą warstwą posadzki, oraz w lokalizacji - posadzka RG10 pokrywa płytę denną, a R10 układana jest na stropie.

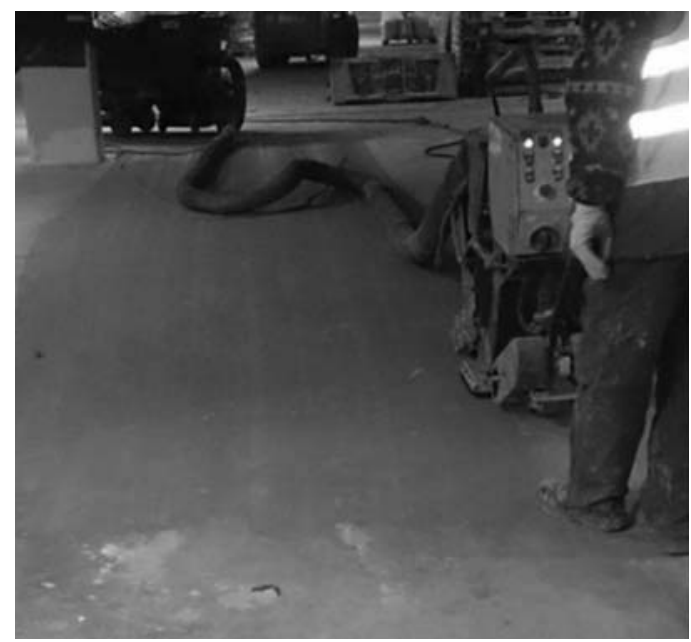

Rys. 1. Przygotowanie podłoża poprzez śrutowanie (fot. A. Majstrowicz)

Fig. 1. Preparation of the substrate by shot blasting (photo by A. Majstrowicz)

\section{WYNIKI}

Posadzki żywiczne na budowie centrum handlowego zostały wykonane z użyciem następującej technologii:

- przygotowanie podłoża - ten etap wykonano poprzez śrutowanie lub (w miejscach do tego niedostępnych) poprzez szlifowanie do stanu wymaganego przez dostawcę systemu posadzkowego (rys. 1);

- badania podłoża - badano wilgotność podłoża za pomocą metody suszarkowo-wagowej, a następnie wykonano badania ,pull-off”; wyniki badań potwierdziły zdatność podłoża do wykonania na nim posadzki żywicznej ${ }^{1}$;

- czyszczenie podłoża za pomocą odkurzaczy przemysłowych (rys. 2);

- uzupełnienie ubytków w podłożu (rys. 3 i 4);

- naprawa przerw roboczych, dylatacji i rys (rys. 5);

- wydzielenie działek roboczych (rys. 6);

- wykonanie posadzki żywicznej - podczas tego etapu wykonawca miał obowiązek prowadzenia nieustannych pomiarów wilgotności podłoża, wilgotności względnej powietrza, temperatury otoczenia oraz określania punktu rosy.

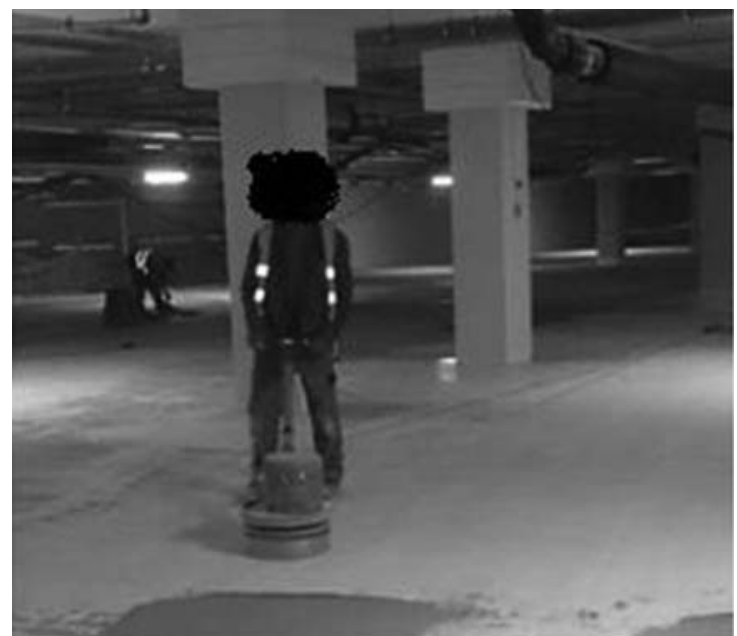

Rys. 2. Czyszczenie podłoża (fot. A. Majstrowicz)

Fig. 2. Cleaning the substrate (photo by A. Majstrowicz)

\footnotetext{
${ }^{1}$ Podłoże musi mieć odpowiednią wytrzymałość na ściskanie - minimum wynosi $25,0 \mathrm{~N} \cdot \mathrm{mm}^{-2}$ (według normy PN-EN 206+A1:2016-12), a minimalna wartość wytrzymałości na odrywanie badana za pomocą metody „pull-off” wynosi $1,5 \mathrm{~N} \cdot \mathrm{mm}^{-2}$ (według normy PN-EN 1542). Nieprzekraczalna wartość wilgotności podłoża wynosi 4\% wagowo.
} 


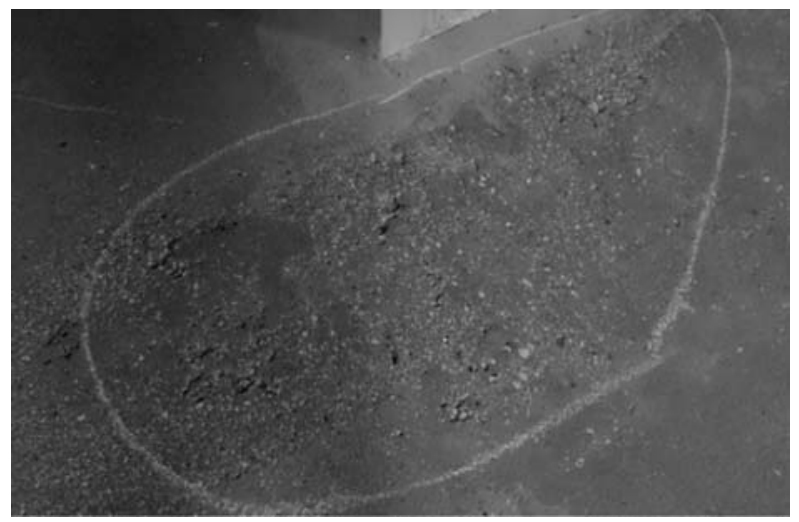

Rys. 3. Oznaczenie miejsca w podłożu wymagające uzupełnienia ubytków (fot. A. Majstrowicz)

Fig. 3. Marking the place in the ground that requires filling in the cavities (photo by A. Majstrowicz)

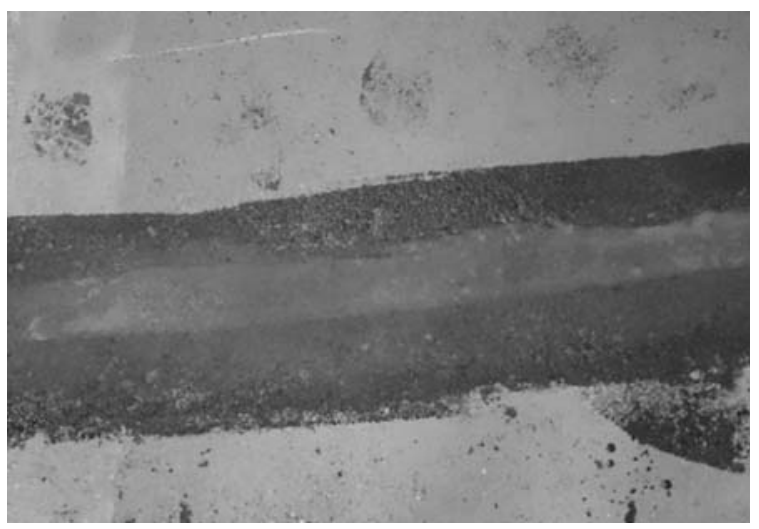

Rys 5. Uszczelnienie dylatacji (fot. A. Majstrowicz)

Fig. 5. Seal the dilatation (photo by A. Majstrowicz)

\section{DYSKUSJA}

Podczas wykonywania posadzek żywicznych należało spełnić wiele restrykcyjnych wymagań (ITB, 2006). W związku z tym już od samego początku zaczęły pojawiać się przeszkody.

\section{Rysy i spękania}

Po wykonaniu śrutowania betonu oraz oczyszczeniu podłoża na powierzchni parkingu poziomu -1 (B1) zaczęły być widoczne rysy i spękania stropu - zarówno wokół słupów (rys. 7 i 9), jak i pomiędzy nimi (na całej długości pasma stropowego - od słupa do słu-

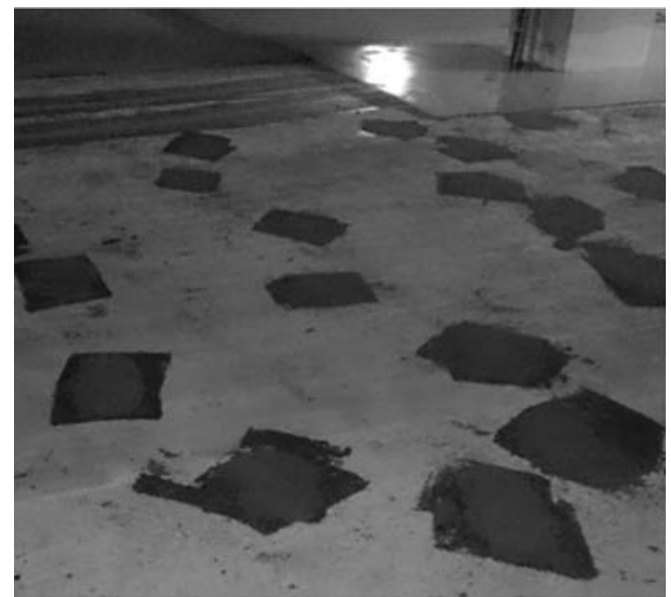

Rys. 4. Lokalne naprawy podłoża (fot. A. Majstrowicz)

Fig. 4. Local ground repairs (photo by A. Majstrowicz)

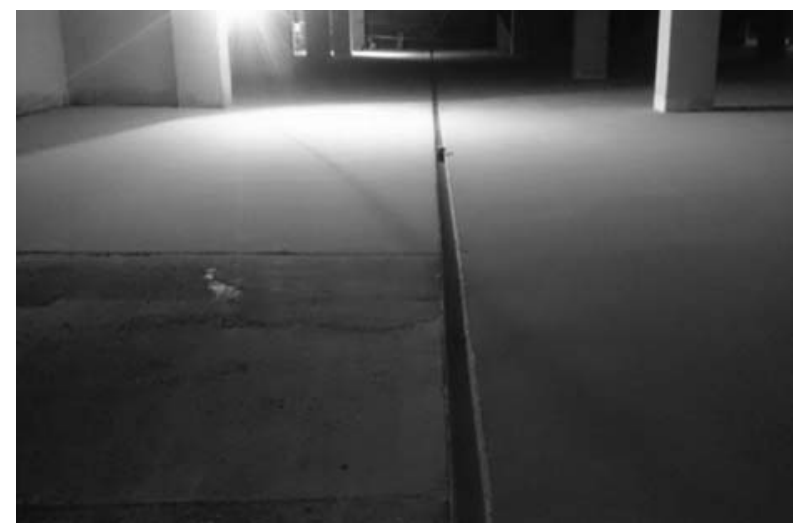

Rys. 6. Widoczny podział na działki robocze (fot. A. Majstrowicz)

Fig. 6. Visible division into working plots (photo by A. Majstrowicz)

pa; rys. 8). Powyższe zjawisko wystąpiło wyłącznie $\mathrm{w}$ jednym kierunku - w drugim kierunku nie zaobserwowano zjawiska na taką skalę. Na poziomie -2 (B2) rysy i spękania były o wiele mniej zauważalne.

Wada ta stanowi dużą przeszkodę i zagrożenie dla poprawnego wykonania posadzki żywicznej. Generalny wykonawca podjął kroki, których celem było ustalenie genezy rys oraz wdrożenie programu naprawczego. Konstruktor obiektu stwierdził, że występujące w stropie rysy mają cechy skurczowych i nie wpływają na bezpieczeństwo konstrukcji. Są to typowe defekty powstałe przy wysychaniu betonu, a uwydatnione podczas przygotowywania powierzchni pod ułożenie 


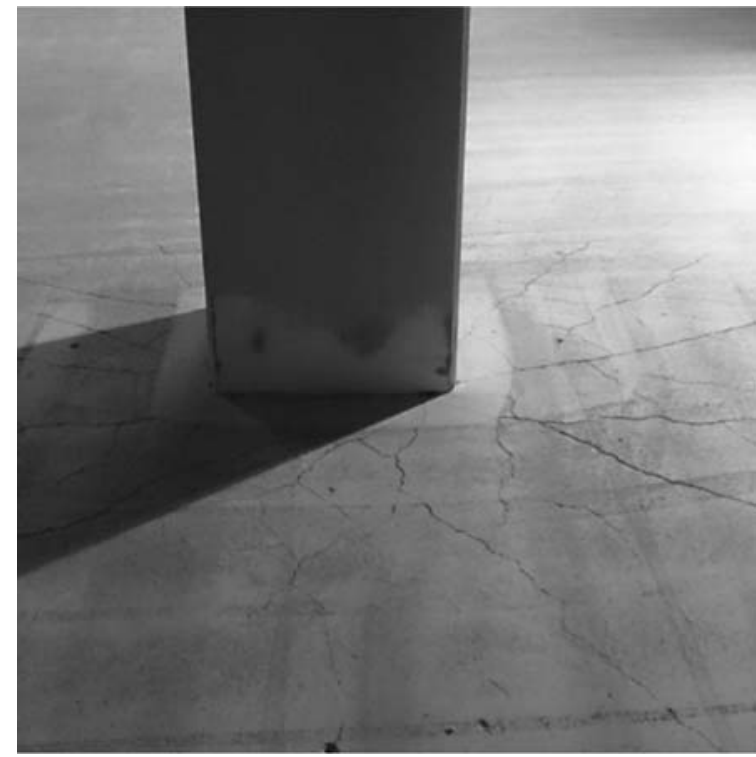

Rys. 7. Widoczne promieniste rysy wokół słupa na kondygnacji -1 (fot. A. Majstrowicz)

Fig. 7. Visible radiant scratches around the column on the floor -1 (photo by A. Majstrowicz)

żywicy. Wyniki przewiertów przez rysy, które zostały wykonane w stropie parkingu podziemnego, potwierdzały, że nie biegną one przez cały przekrój stropu, a kończą się na siatce zbrojenia górnego. Projektant ocenił, że powstałe rysy nie przekraczają granicznej wartości $0,2 \mathrm{~mm}$ oraz że nie ulegną rozszerzeniu podczas okresu użytkowania obiektu. Nie było więc przeszkód w wykonaniu posadzki żywicznej.

Chcąc upewnić się co do stanu stropu, zlecono wykonanie ekspertyzy technicznej zarysowań stropu nad kondygnacją -2. Potwierdzono, że pomimo uszkodzeń w pełni nadaje się on do wykorzystania zgodnego z przeznaczeniem, ale same rysy wymagają prac naprawczych.

Propozycja prac naprawczych (rys. 10 i 11) przygotowana została przez dostawcę materiału do wykonania posadzki. Zgodnie z nią należało:

- dokonać śrutowania posadzki w obrębie słupów;

- odkurzyć powierzchnię wymagającą naprawy;

- sprawdzić, czy beton ma odpowiednią wytrzymałość na odrywanie (nie może być mniejsza niż 1,5 MPa);

- wykonać iniekcję grawitacyjną z użyciem żywicy epoksydowej, a następnie pod docelową posadzkę żywiczną wkleić matę żywiczną z włókna szklanego - w przypadku rys podłużnych pomiędzy słupami;

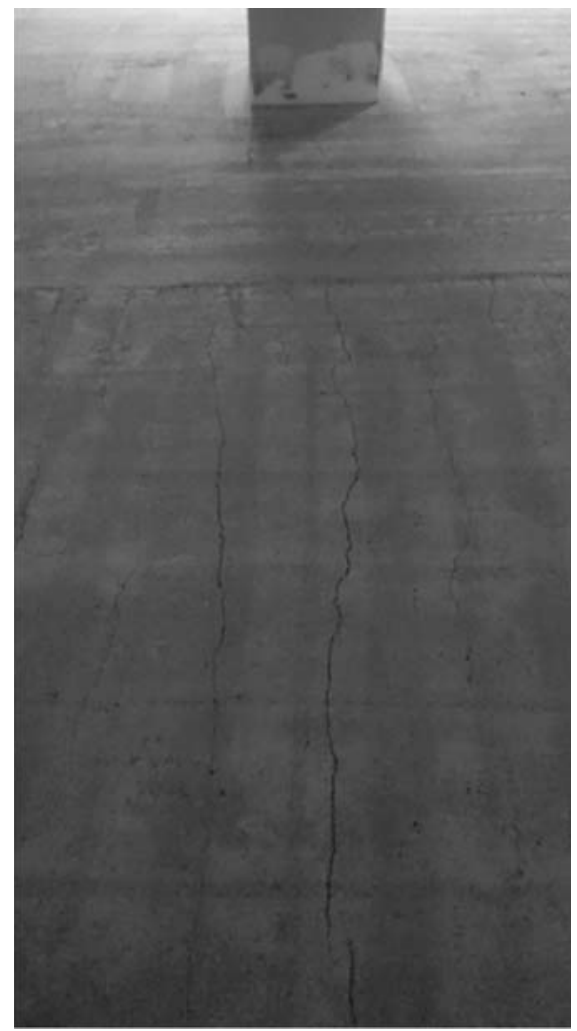

Rys. 8. Widoczne rysy pomiędzy słupami na kondygnacji -1 (fot. A. Majstrowicz)

Fig. 8. Visible scratches between the columns on the storey -1 (photo by A. Majstrowicz)

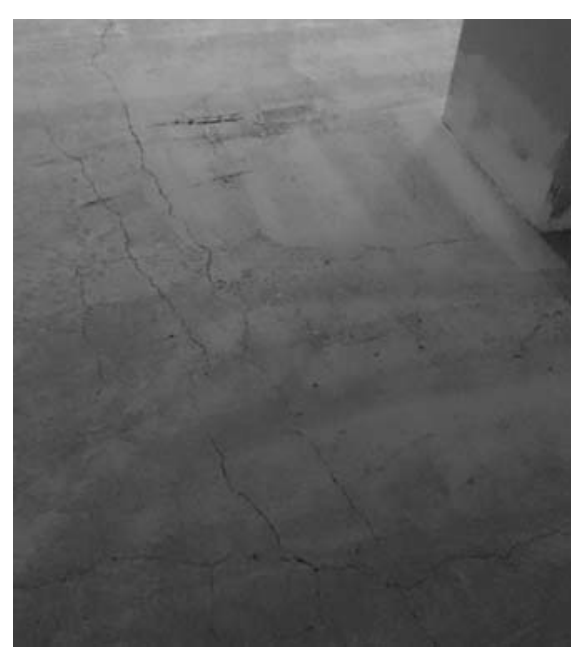

Rys. 9. Widoczne rysy w obrębie słupa na kondygnacji -1 (fot. A. Majstrowicz)

Fig. 9. Visible scratches within the column on the storey -1 (photo by A. Majstrowicz) 
Dąbkowski, N., Majstrowicz, A. (2019). Problemy wykonawcze przy posadzce żywicznej w galerii handlowej. Acta Sci. Pol. Architectura 18 (2), 107-114, DOI: 10.22630/ASPA.2019.18.2.27

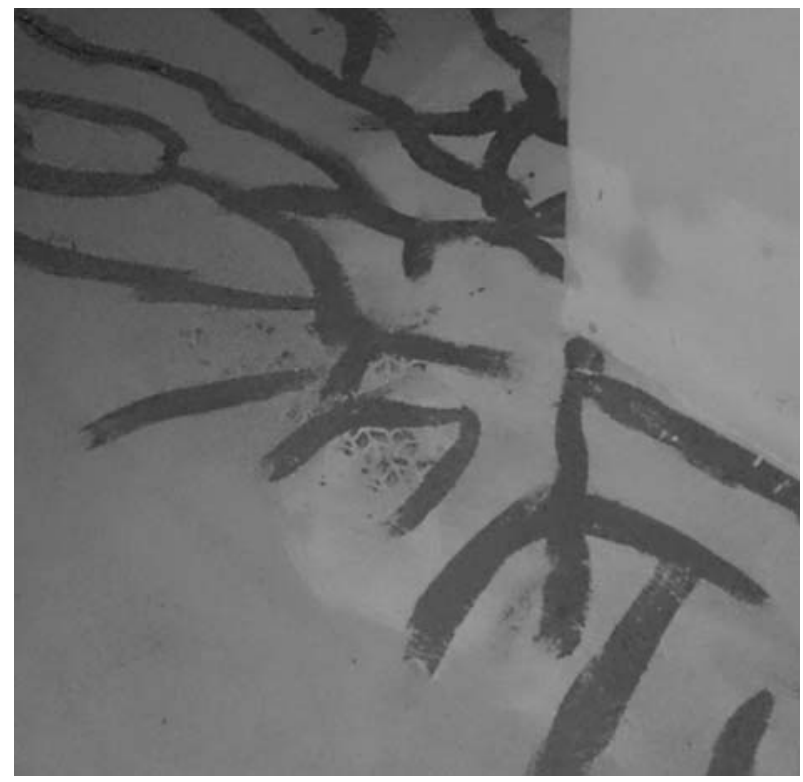

Rys. 10. Widok poszczególnych rys kondygnacji 1 po wykonaniu naprawy (fot. A. Majstrowicz)

Fig. 10. View of individual features of floor 1 after repair (photo by A. Majstrowicz)

- wykonać dodatkową warstwę membrany elastycznej w przypadku rys promienistych wokół słupów.

\section{Pęcherze powietrzne}

Powstałe w stropie rysy nie były jedyną przeszkodą w realizacji wykończenia żywicą na parkingu podziemnym. W trakcie wykonywania posadzki R10 na poziomie B1 (kondygnacja-1), po nałożeniu warstwy zamykającej, na powierzchni stropu zaczęły pojawiać się pęcherze powietrzne (rys. 12).

Przyczyna może leżeć w niewystarczającym zagruntowaniu podłoża, które było zbyt porowate i chłonne w górnej warstwie. Nabrało ono tych cech, ponieważ było wykonywane w okresie zimowym i niekorzystnych warunkach atmosferycznych, co przysporzyło trudności $\mathrm{w}$ prawidłowym zatarciu betonu oraz jego odpowietrzeniu. W związku $\mathrm{z}$ tym pozostały w podłożu nadmiar powietrza utworzył w strukturze betonowej pory połączone ze sobą w system kapilar. W skutek wykonania mechanicznego zacierania stropu zostały one przypowierzchniowo zamknięte. W wyniku przygotowania podłoża pod posadzkę żywiczną poprzez śrutowanie i frezowanie

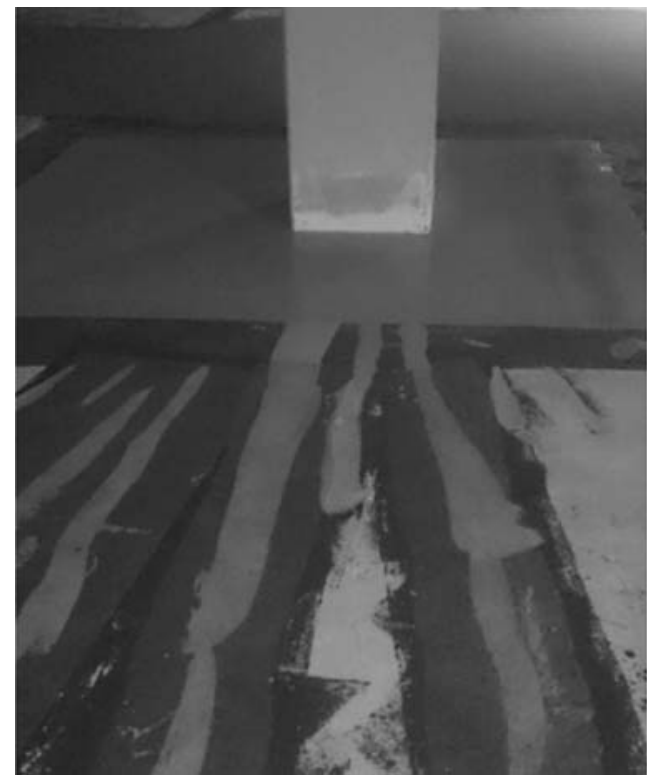

Rys. 11. Widok rys kondygnacji -1 po wykonaniu naprawy powierzchniowej (fot. A. Majstrowicz)

Fig. 11. View of floor plan -1 after surface repair (photo by A. Majstrowicz)

nastąpiło odsłonięcie powstałych kapilar, które zostały po części wypełnione gruntującą warstwą żywicy. Następnie z powodu wzrostu temperatury, wywołanego egzotermiczną reakcją wytwarzaną podczas procesu twardnienia żywicy, powietrze $\mathrm{w}$ kapilarach zaczęło się rozszerzać - pory przedostawały się w górne warstwy posadzki, powodując powstanie tzw. baniek powietrznych. Opisane zjawisko było widoczne dopiero w warstwie zamykającej posadzki, a nie na każdym etapie jej wykonywania.

Podjęto także próby wykonania posadzki z użyciem materiałów innego producenta. Efekt był taki sam jak w przypadku materiałów pierwotnego dostawcy.

Za przyczynę zjawiska można uznać zbyt dużą grubość warstwy pośredniej. Posadzka na poziomie -2 miała identyczny układ warstw co na poziomie -1 , z tym wyjątkiem, że warstwa pośrednia była zaprojektowana jako cieńsza. Na piętrze B2 (kondygnacja -2) nie zaobserwowano pęcherzy powietrznych. W związ$\mathrm{ku} \mathrm{z}$ tym zmieniono technologię wykonywania posadzki na stropie B1 (kondygnacja -1). Polegała ona na tym, że układano dwa razy cieńszą warstwę pośrednią, zamiast jednej grubej powłoki. Ten zabieg pozwo- 

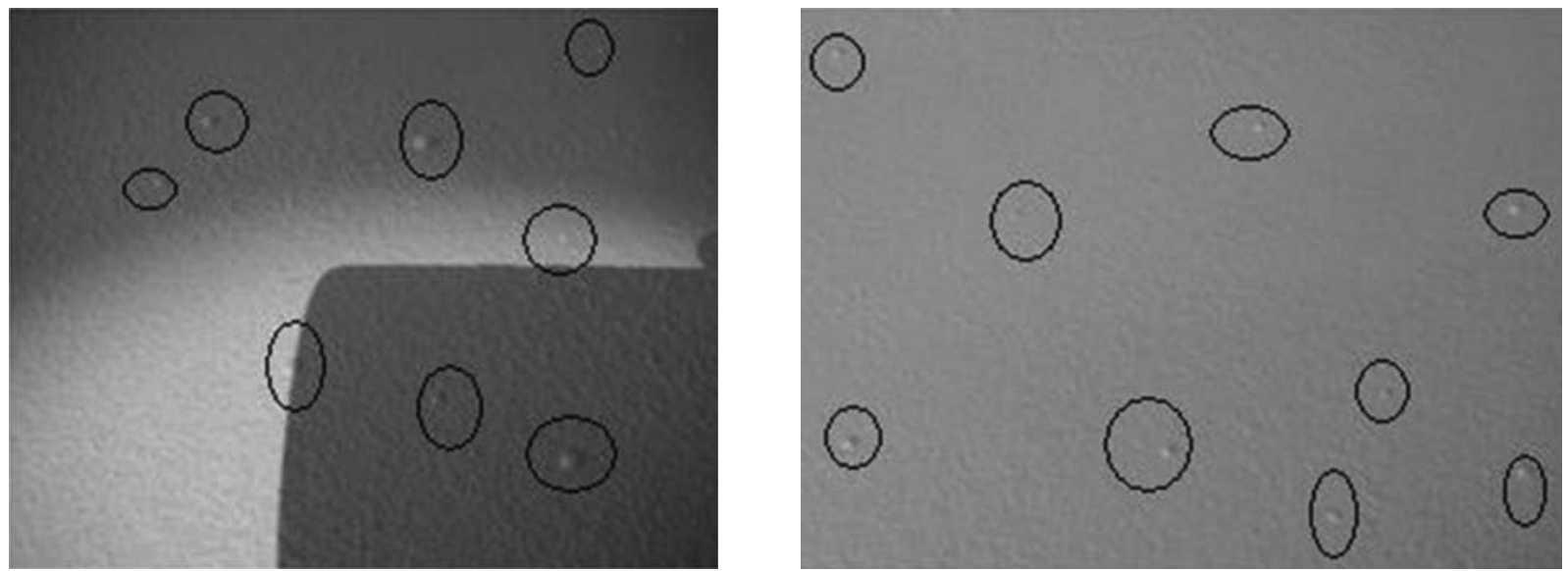

Rys. 12. Pęcherze powietrzne które pojawiły się na posadzce żywicznej kondygnacji -1 (fot. A. Majstrowicz)

Fig. 12. Air blisters that appeared on the floor of the resin storey -1 (photo by A. Majstrowicz)

lił wyeliminować powstawanie baniek powietrznych (rys. 13 i 14).

Jako inny powód powstania opisanego zjawiska można przyjąć stosowanie różnego rodzaju domieszek do betonu (PN-EN 934-1:2009; PN-EN 934-2+A1:2012; Jamroży, 2015). Nie jest zalecane ich używanie, jeśli wykończeniem ma być posadzka żywiczna. W wyniku tego może zajść wiele reakcji che-

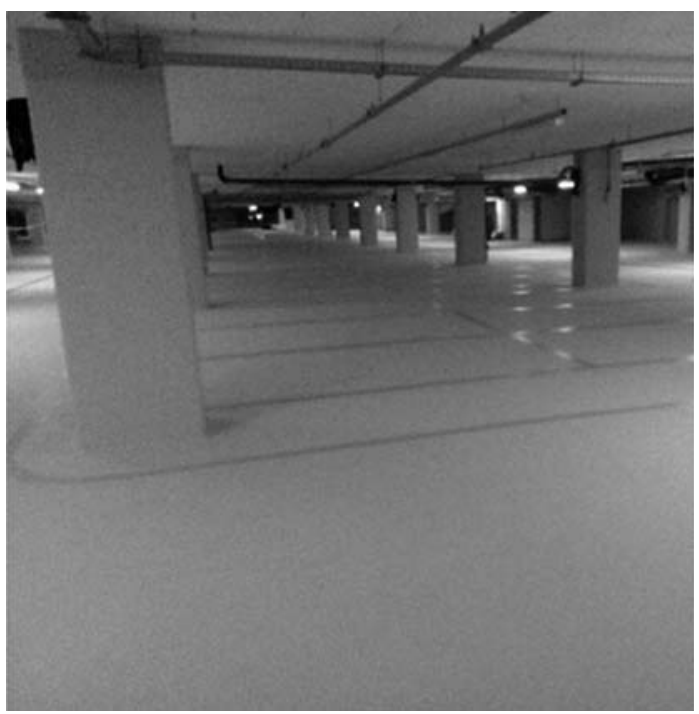

Rys. 13. Prawidłowo wykonana posadzka żywiczna kondygnacji-1 (fot. A. Majstrowicz)

Fig. 13. A properly made floor resin storey -1 (photo by A. Majstrowicz) micznych prowadzacych do wadliwego wykonania wykończenia.

Kolejną przyczyną może być to, że mieszankę żywiczną poddaje się coraz większym modyfikacjom ze względów ekonomicznych. W wyniku tego w materiale na posadzkę znajduje się mniej żywicy, która zostaje zastąpiona innymi substancjami chemicznymi, co teoretycznie nie powinno wpływać na jej właściwości, ale nie jest też wykluczone, że te modyfikacje wpływają na jakość wykonania dobrej jakościowo posadzki. Oddziałuje to na czas rozpływu mieszanki

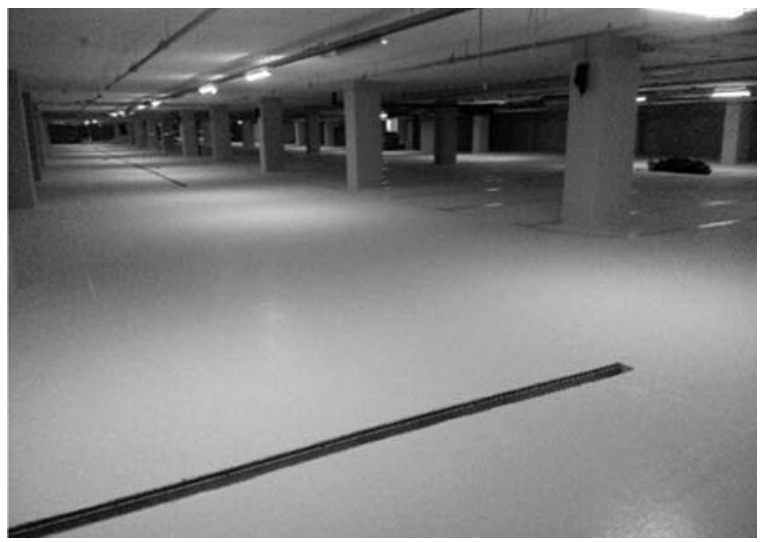

Rys. 14. Prawidłowo wykonana posadzka żywiczna kondygnacji $-1 \quad \mathrm{z}$ widocznym odwodnieniem (fot. A. Majstrowicz)

Fig. 14. A properly made resin floor of storey -1 with visible drainage (photo by A. Majstrowicz) 
oraz czas jej schnięcia. W przypadku wykonawstwa $\mathrm{w}$ analizowanym obiekcie stosowano nagrzewnice - posadzka była wykonywana zimą, więc należało zapewnić odpowiednią temperaturę otoczenia. Prawdopodobnie postawiono nagrzewnice o zbyt dużej mocy, co spowodowało, że posadzka nagrzała się w górnej części, podczas gdy podłoże betonowe miało temperaturę o wiele niższą. Spowodowało to twardnienie żywicy od wierzchniej warstwy, co wywołało ruch zamkniętego powietrza ku górze i powstanie porów.

Co więcej, posadzkę żywiczną powinno układać się na podkładzie betonowym po 28 dniach od jego wylania. W przypadku opisywanego obiektu czynności te zostały przyśpieszone $\mathrm{z}$ uwagi na krótki czas realizacji. Posadzka była wykonywana ok. 2-3 tygodni od czasu zakończenia wylewania podkładów betonowych, co niewątpliwie miało wpływ na efekt końcowy.

\section{PODSUMOWANIE}

Nawierzchnia danego obiektu stanowi jedną z jego wizytówek. Wchodząc do obiektu, w pierwszej kolejności nie spoglądamy w kierunku sufitu. Nasz wzrok przykuwa posadzka. Stosując posadzkę żywiczną, do wyboru jest kilka opcji - zależne od wymagań stawianych posadzce oraz od efektu, jaki finalnie chcemy osiągnąć. Dobór odpowiedniego produktu jest obecnie bardzo szeroki zarówno tych o prostym składzie, jak i złożonym wieloskładnikowym, o fakturze antypoślizgowej lub gładkiej. Posadzki żywiczne można wykonać w dowolnym kolorze.

Ważnym aspektem wpływającym na jakość produktu końcowego (posadzki) jest przestrzeganie reżimów czasowych i technologicznych podczas wykonywania posadzki, a także na etapie przygotowania podłoża.

Podsumowując, posadzka żywiczna jest rozwiązaniem spełniającym swoje przeznaczenie w przestrzeniach zadaszonych, na odpowiednio przygotowanym podłożu i przy prawidłowym wykonaniu.

\section{PIŚMIENNICTWO}

Chmielewska, B. (2007). Rozwiązania materiałowo technologiczne posadzek przemysłowych. W I Seminarium Naukowo-Techniczne „Podtogi Przemystowe”, Warszawa, 25.10.2007 (strony 58-63).

Czarnecki, L. (2008). Posadzki przemysłowe - temat stale aktualny. Materiaty Budowlane, 9, 2-4

Instytut Techniki Budowlanej [ITB] (2006). Warunki techniczne wykonania i odbioru robót budowlanych. Część B: Roboty wykończeniowe. Zeszyt 3: Posadzki mineralne i żywiczne. Warszawa.

Jamroży, Z. (2015). Beton i jego technologie. Warszawa: Wydawnictwo Naukowe PWN.

Karwacki, J. (2002). Posadzki przemysłowe, zasady ich projektowania oraz unikania najczęściej występujących usterek. Podtoga, 9, $38-41$.

PN-EN 1542. Wyroby i systemy do ochrony i napraw konstrukcji betonowych. Metody badań: Pomiar przyczepności przez odrywanie.

PN-EN 206+A1:2016-12. Beton. Wymagania, właściwości, produkcja i zgodność.

PN-EN 934-1:2009. Domieszki do betonu, zaprawy i zaczynu. Część 1: Wymagania podstawowe.

PN-EN 934-2+A1:2012. Domieszki do betonu, zaprawy i zaczynu. Część 2: Domieszki do betonu. Definicje, wymagania, zgodność, oznakowanie i etykietowanie.

Tejchman, J. i Małasiewicz, A. (2006). Posadzki przemystowe. Gdańsk: Wydawnictwo Politechniki Gdańskiej.

\title{
IMPLEMENTING PROBLEMS WITH A VARIETY FLOOR IN A COMMERCIAL GALLERY
}

\begin{abstract}
The article concerns problems that occurred during the finishing of the floor in the Warsaw shopping mall. The issue was related mainly to ceiling surface on which the floors were to be made (air bubbles on the top layer of the resin floor). The paper presents structure of two resin floors, technological phases of their construction and discusses the possible causes of the problem. Finally, the authors presented the repair works that were carried out.
\end{abstract}

Key words: resin floor, floor, workmanship 


\title{
OCENA WŁAŚCIWOŚCI FIZYCZNYCH I MECHANICZNYCH KOMPOZYTU GLINOWEGO Z DODATKIEM SŁOMY POD KĄTEM WYKORZYSTANIA W BUDOWNICTWIE
}

\author{
Krzysztof Wiśniewski ${ }^{1}$, Agata Pawłat-Zawrzykraj ${ }^{1 凶}$, Maja Urbańska² \\ ${ }^{1}$ Wydział Budownictwa i Inżynierii Środowiska, Szkoła Główna Gospodarstwa Wiejskiego w Warszawie, Warszawa \\ 2 Skanska S.A.
}

\begin{abstract}
STRESZCZENIE
W pracy przedstawiono wyniki badań wybranych właściwości fizycznych i mechanicznych kompozytu glinowego z dodatkiem słomy i piasku kwarcowego. Zawartość gliny w badanych próbkach wahała się od 63 do 53\%, słomy 5-13\%, piasku 4-10\%. Wykonano badanie skurczu, gęstości, wytrzymałości na zginanie oraz wytrzymałości na ściskanie. Uzyskane wyniki wskazują na korzystny wpływ dodatków na badane właściwości. Wraz ze wzrostem zawartości słomy oraz piasku kwarcowego malał skurcz suszenia, rosła wytrzymałość na ściskanie i zginanie. Najlepsze wyniki uzyskano dla próbek zawierających 58\% gliny, 9\% słomy, $6 \%$ - piasku, 27\% wody. Uzyskane wyniki badań wskazują na przydatność badanego kompozytu jako materiału do wznoszenia konstrukcji nośnych budynków.
\end{abstract}

Słowa kluczowe: glina, słoma, materiały budowlane, skurcz, wytrzymałość

\section{WSTĘP}

Budownictwo z gliny znane jest i stosowane od dawna, ale w ostatnim czasie zyskuje na popularności m.in. z uwagi na swój niski stopień energochłonności. Glina jako materiał nieprzetworzony uznawana jest za produkt przyjazny dla środowiska naturalnego, a także materiał sprzyjający wytworzeniu odpowiedniego mikroklimatu wewnątrz pomieszczeń w budynkach wznoszonych z tego materiału (Hyła i Kupiec-Hyła, 1994; Kamieniarz, 2010; Szuba, 2011; Minke, 2012; Backiel-Brzozowska, 2014; Wiśniewski, Geniusz i Pawłat-Zawrzykraj, 2018).

Budownictwo z gliny w Polsce przechodziło różne koleje losu np. w latach czterdziestych i pięćdziesiątych
XX wieku powstało kilkadziesiąt obiektów budownictwa mieszkaniowego i inwentarskiego, ale nigdy budownictwo z gliny nie stało się powszechne. Ten rodzaj technologii wznoszenia budynków powszechnie był uznawany za budownictwo dla ubogich, substandardowe, realizowane często w sposób nieprawidłowy.

Obecnie rozwój technologii stosowanych w budownictwie jest w dużej mierze wynikiem dostosowywania się polskiego prawodawstwa do standardów europejskich. Te zaś są odzwierciedleniem dążenia do budownictwa energooszczędnego, przyjaznego środowisku naturalnemu nie tylko w czasie eksploatacji, ale także na etapie produkcji materiałów budowlanych, a nawet $\mathrm{w}$ czasie rozbiórki i utylizacji następującej po zużyciu technicznym. Jednym $\mathrm{z}$ rozwiązań wy-

$凶$ agata_pawlat_zawrzykraj@sggw.pl 
chodzących naprzeciw tego rodzaju potrzebom rynku budowlanego może być glina - naturalny materiał, jak już wspomniano, niewymagający dużych nakładów energetycznych, a w związku z tym dużych kosztów produkcji, transportu i robocizny (Wiśniewski i in., 2018). Większość realizowanych budynków wznoszona jest systemem gospodarczym. Niestety zainteresowanie firm budowlanych, głównie ze względu na mała rentowność tego rodzaju realizacji, jest nadal niewielkie.

Norma branżowa BN-62/6738-02, dotycząca budownictwa $\mathrm{z}$ gliny, określa masy gliniane jako mieszaninę gliny $\mathrm{z}$ wypełniaczami mineralnymi bądź organicznymi. Mogą być one zastosowane do produkcji materiałów o różnym przeznaczeniu, zarówno jako konstrukcyjne bloczki ścienne, belki, nadproża drzwiowe oraz okienne, jak i bloczki ścienne do ścian działowych i wypełniających, płyty ocieplające, płyty stropowe i dachowe. Norma narzuca ograniczenia w budowlanym wykorzystaniu mas glinianych do budynków o maksymalnie trzech kondygnacjach, o małym i średnim zawilgoceniu.

Gliny charakteryzują się dość znacznym zróżnicowaniem składu chemicznego i mineralogicznego, który wpływa bezpośrednio na cechy mechaniczne i fizyczne materiałów $\mathrm{z}$ nich wytwarzanych. $\mathrm{Z}$ tego względu każdorazowo należy przeprowadzić badania gęstości objętościowej, wytrzymałości na ściskanie, wrażliwości na suszenie i skurcz suszenia. Zgodnie z normą BN-62/6738-02 wyróżniane są trzy rodzaje gliny: ciężka, średnio ciężka, lekka.

Określenia te odnoszą się do masy $1 \mathrm{~m}^{3}$ kompozytów z gliny i tak dla:

- glin ciężkich średnia gęstość wynosi do $1800 \mathrm{~kg} \cdot \mathrm{m}^{-3}$,
- glin średnio ciężkich średnia gęstość wynosi 1200$-1700 \mathrm{~kg} \cdot \mathrm{m}^{-3}$,

- glin lekkich średnia gęstość wynosi $600-1200 \mathrm{~kg} \cdot \mathrm{m}^{-3}$. W publikacjach autorstwa Hyły i Kupiec-Hyła (1994) oraz Minke (2012) analizowano głównie rozwiązania z zastosowaniem tzw. glin lekkich. W pracy wykorzystano kompozyty glinowe z gliny odpowiadającej parametrom gliny średnio ciężkiej, z różną ilością dodatków włóknistych (słoma cięta) i piasku kwarcowego w celu odwrażliwienia gliny na możliwość pękania w trakcie suszenia. O ile piasek kwarcowy wpływa na skurcz suszenia i ograniczenie możliwości pękania kompozytu glinowego, o tyle dodatek sieczki słomianej miał za zadanie poprawę właściwości cieplnych i mechanicznych (Racięcki, 1962).

Celem pracy jest zbadanie wybranych właściwości fizycznych oraz mechanicznych kompozytu glinowego o różnej zawartości słomy oraz piasku w celu określenia jego przydatności do celów budowlanych.

\section{MATERIA I METODY}

Do wykonania badania wykorzystano glinę pochodzącą z nadkładu gruntów Kopalni Węgla Brunatnego „Bełchatów”. Osady występujące w rejonie bełchatowskiej odkrywki zaliczane są do osadów neogenu poznańskiego, kompleksu ilasto-piaszczystego, który tworzy kilka pokładów zalegających w uskokach brzeżnych i osiągających grubość 40-50 m (Ratajczak i Hycnar, 2017).

Podstawowym minerałem użytej gliny jest beidelit z nieznaczną zawartością kwarcu oraz kaolinitu (Hycnar, Jończyk i Ratajczak, 2017). Skład chemiczny badanego materiału przedstawiono $\mathrm{w}$ tabeli 1.

Tabela 1. Skład chemiczny gliny

Table 1. The chemical composition of the clay

\begin{tabular}{lccc}
\hline $\begin{array}{l}\text { Składniki } \\
\text { Components }\end{array}$ & $\begin{array}{c}\text { Zawartość [\%wag.] } \\
\text { Content [wt\%] }\end{array}$ & $\begin{array}{c}\text { Składnik } \\
\text { Components }\end{array}$ & $\begin{array}{c}\text { Zawartość [\%wag.] } \\
\text { Content [wt\%] }\end{array}$ \\
\hline $\mathrm{SiO}_{2}$ & 61,57 & $\mathrm{TiO}_{2}$ & 0,47 \\
$\mathrm{Al}_{2} \mathrm{O}_{3}$ & 26,48 & $\mathrm{P}_{2} \mathrm{O}_{5}$ & 0,16 \\
$\mathrm{Fe}_{2} \mathrm{O}_{3}$ & 3,57 & $\mathrm{SO}_{3}$ & 0,10 \\
$\mathrm{CaCO}_{3}$ & 2,54 & $\mathrm{Na}_{2} \mathrm{O}$ & 0,06 \\
$\mathrm{CaO}$ & 1,42 & $\mathrm{MnO}$ & 0,02 \\
$\mathrm{MgO}$ & 1,04 & straty prażenia - loss on ignition & 3,86 \\
$\mathrm{~K}_{2} \mathrm{O}$ & 0,65 & części organiczne - organic components & 0,50 \\
\hline
\end{tabular}


Poszczególne etapy przygotowania gliny obejmowały:

- suszenie w suszarce laboratoryjnej (temperatura suszenia $60^{\circ} \mathrm{C}$, czas suszenia $48 \mathrm{~h}$ ),

- rozdrobnienie na drobne frakcje w młynie kulowym,

- przesianie przez sito o wielkości oczek $2 \mathrm{~mm}$.

Uzyskany materiał podzielono na cztery części na potrzeby czterech serii badań, następnie dodano w różnych proporcjach piasek, słomę i wodę. Funkcję zbrojenia rozproszonego dla bloczków wykonanych z gliny pełniła słoma żytnia, której łodygi pocięto na 2-3-centymetrowe włókna.

Kruszywo to piasek kwarcowy frakcji $1 \mathrm{~mm}$. Procentową zawartość gliny, słomy, piasku i wody w poszczególnych seriach badań $\mathrm{w}$ przedstawiono w tabeli 2 . tym kapilary mają mniejszy przekrój i utrudniają swobodne odparowywanie wody. Z tego powodu wymagają one dłuższego suszenia niż gliny o mniejszej zawartości substancji ilastych. Tę niekorzystną sytuację w przypadku glin tłustych można zmienić, dodając tzw. materiałów schudzających, np. piasku kwarcowego lub granulowanego materiału ceramicznego (np. gruz ceglany).

Badanie skurczu zostało wykonane na belkach o wymiarach $40 \times 40 \times 160 \mathrm{~mm}$. Metoda badania skurczu polegała na określenie zmiany odległości nacięć wykonanych na belce przed suszeniem i po całkowitym wysuszeniu. Pomiary odległości między nacięciami zmierzono za pomocą suwmiarki elektronicznej z dokładności do $0,5 \mathrm{~mm}$. Procentowy skurcz próbek obliczono zgodnie ze wzorem (1):

Tabela 2. Skład ilościowy kompozytu glinowego

Table 2. Quantitative composition of the clay composite

\begin{tabular}{ccccc}
\hline \multirow{2}{*}{$\begin{array}{c}\text { Nr serii } \\
\text { Series no. }\end{array}$} & \multicolumn{4}{c}{ Skład mieszanki - Mixture composition [\%] } \\
\cline { 2 - 5 } & $\begin{array}{c}\text { glina } \\
\text { clay }\end{array}$ & $\begin{array}{c}\text { słoma } \\
\text { straw }\end{array}$ & $\begin{array}{c}\text { piasek } \\
\text { sand }\end{array}$ & $\begin{array}{c}\text { woda } \\
\text { water }\end{array}$ \\
\hline I & 68 & 0 & 0 & 32 \\
II & 63 & 5 & 4 & 28 \\
III & 58 & 9 & 6 & 27 \\
IV & 53 & 13 & 10 & 24 \\
\hline
\end{tabular}

$\mathrm{Na}$ potrzeby niniejszego badania uformowano 12 próbek o wymiarach $100 \times 100 \times 100 \mathrm{~mm}$ oraz 12 belek o wymiarach $40 \times 40 \times 160 \mathrm{~mm}$, które następnie dla uniknięcia gwałtownego skurczu poddano dwuetapowemu powolnemu suszeniu do momentu uzyskania stałej masy. W pierwszej kolejności (48 h) próbki suszono w temperaturze pokojowej, w końcowej fazie $(24 \mathrm{~h})-\mathrm{w}$ temperaturze $105^{\circ} \mathrm{C}$. Przyjęty sposób suszenia wynikał z tego, że próbki zerowe bez dodatków w czasie suszenia wykazywały bardzo silny skurcz i skłonność do pękania (rys. 1). Szybkość dyfuzji wody z wnętrza próbek na zewnątrz jest zależna od zawartości substancji ilastych, co jest związane m.in. z wielkością kapilar. Im glina ,jest bardziej thusta”, czyli im więcej minerałów ilastych,

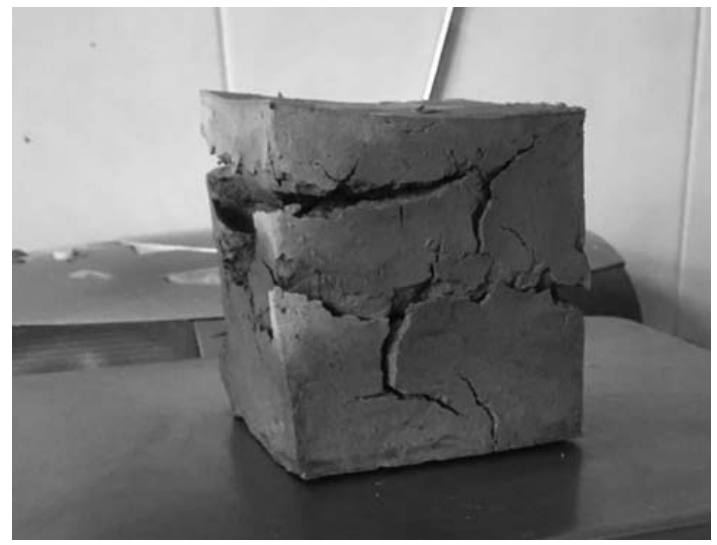

Rys. 1. Silne spękania próbki w wyniku skurczu suszenia

Fig. 1. Strong cracks of the sample as a result of contraction of the drying 
$S=\frac{l-l_{s}}{l} \cdot 100 \%$

gdzie:

$S-\operatorname{skurcz}[\%]$,

$l$ - odległość między poprzecznymi nacięciami po uformowaniu próbki $[\mathrm{mm}]$,

$l_{S}$ - odległość między poprzecznymi nacięciami po wyschnięciu próbki [mm].

Gęstość objętościowa próbek sześciennych oraz belek została obliczona zgodnie ze wzorem (2), z wykorzystaniem wartości uzyskanych przed suszeniem i po ich wysuszeniu.

$\rho_{0}=\frac{m}{v}$

gdzie:

$\rho_{0}-$ gęstość objętościowa $\left[\mathrm{kg} \cdot \mathrm{m}^{-3}\right]$,

$m$ - masa próbki $[\mathrm{kg}]$,

$V$ - objętość próbki $\left[\mathrm{m}^{3}\right]$.

Badanie wytrzymałości na zginanie wykonano na próbkach belek o wymiarach $40 \times 40 \times 160 \mathrm{~mm}$. Przyjęto przypadek obciążenia działającego na środek belki. Na podstawie uzyskanej wartości siły zginającej obliczona została wytrzymałość na zginanie belki zgodnie ze wzorem (3).

$f_{c f}=\frac{M_{\max }}{W_{z}}$

gdzie:

$f_{c f}$-wytrzymałość na zginanie $\left[\mathrm{kN} \cdot \mathrm{mm}^{-2}\right]$,

$M_{\max }-$ maksymalny moment zginający [kNmm],

$W_{z}$ - wskaźnik wytrzymałość na zginanie $\left[\mathrm{mm}^{3}\right]$.

Wskaźnik wytrzymałości na zginanie obliczono według wzoru (4).

$W_{z}=\frac{b \cdot h^{2}}{6}$

gdzie:

$W_{z}$ - wskaźnik wytrzymałość na zginanie $\left[\mathrm{mm}^{3}\right]$,

$b$ - szerokość belki [mm],

$h$-wysokość belki [mm].
Maksymalny moment zginający obliczono ze wzo$\mathrm{ru}(5)$.

$M_{\text {max }}=\frac{P \cdot l}{4}$

gdzie:

$M_{\max }$ - maksymalny moment zginający [kNmm],

$P$ - siła niszcząca $[\mathrm{kN}]$,

$l$ - odległość między podparciami belki [mm],

Badanie wytrzymałości gliny na ściskanie przeprowadzono na próbkach o wymiarach $100 \times 100 \times 100 \mathrm{~mm}$. Celem było wyznaczenie maksymalnego naprężenia ściskającego, jakie jest w stanie przenieść sześcienna próbka kompozytu glinowego. Badanie wykonano w maszynie wytrzymałościowej, w której jednostajnie zwiększano siłę niszczącą do momentu zniszczenia próbek. Wytrzymałość na ściskanie obliczono zgodnie ze wzorem (6).

$f_{c}=\frac{F}{A_{c}}$

gdzie:

$f_{c}$ - wytrzymałość na ściskanie [MPa],

$F$ - maksymalne obciążenie przy zniszczeniu [N],

$A_{c}$ - pole przekroju poprzecznego próbki, na które działa siła ściskająca $\left[\mathrm{mm}^{2}\right]$.

\section{WYNIKI}

Na podstawie wykonanych badań kompozytu glinowego, składającego się z gliny, ciętej słomy, piasku kwarcowego i wody (tab. 2), uzyskano wyniki podstawowych właściwości fizycznych i mechanicznych badanych próbek (tab. 3 i 4). W pierwszej kolejności ustalono gęstość objętościową próbek o różnym składzie dodatków do gliny. Średnia gęstość próbek sześciennych po wysuszeniu wykazuje tendencję wzrostową wraz ze zwiększeniem dodatku piasku kwarcowego (serie II i III) w stosunku do gliny bez dodatków, ale jednocześnie z uwagi na zwiększanie zawartość ciętej słomy w stosunku do piasku kwarcowego gęstość badanych próbek nieznacznie maleje, co zauważono w przypadku serii IV (rys. 2). 


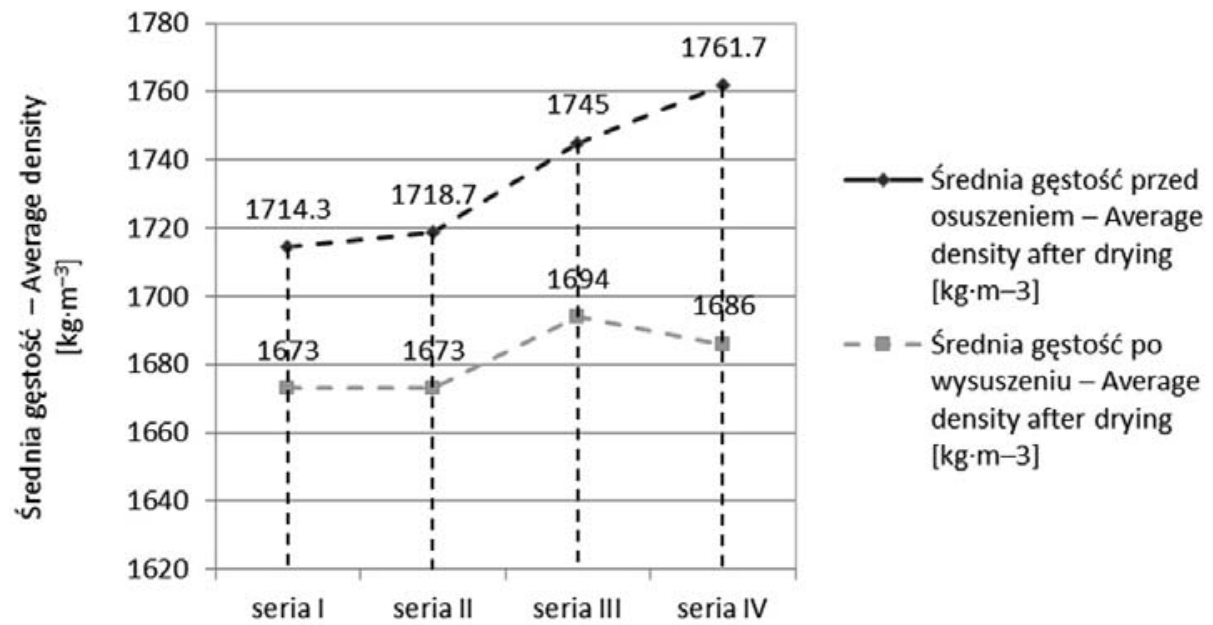

Rys. 2. Średnia gęstość dla próbek sześciennych

Fig. 2. The average density of the cube samples after drying

Skurcz kompozytów glinowych ma istotne znaczenie przy wznoszeniu elementów konstrukcyjnych (ścian zewnętrznych i wewnętrznych). Zbyt duży skurcz może prowadzić do powstawania rys, pęknięć ścian, a w konsekwencji do zmniejszenia wytrzymałości i uszkodzenia budynku. Na podstawie uzyskanych wyników badania skurczu można stwierdzić, że dodatki w postaci ciętej słomy i piasku kwarcowego wpływają na zmniejszenie skurczu badanych próbek kompozytu glinowego (tab. 3). Podobny efekt można uzyskać, stosując dodatek popiołu lotnego (Wiśniewski i Ziółkowska, 2014). Jednakże dodatek popiołu wpływa na zmniejszenie wytrzymałości na ściskanie i zginanie. W przypadku dodatków w postaci ciętej słomy i piasku kwarcowego obserwuje się zwiększenie średniej wytrzymałości na ściskanie w porównaniu do próbek zerowych. Maksymalną wytrzymałość na ściskanie otrzymano dla próbek serii III $(2,18 \mathrm{MPa})$, a najmniejszą dla próbek serii I, czyli zerowych $(1,81 \mathrm{MPa})$ - rysunek 3 .

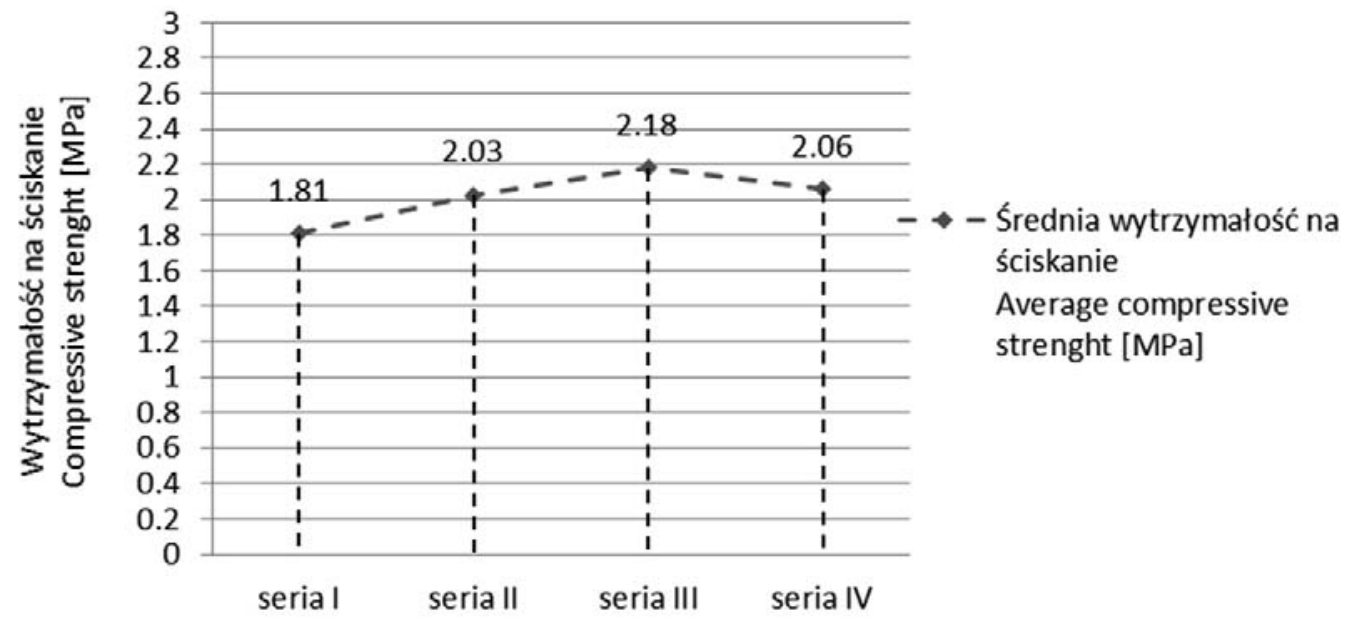

Rys. 3. Wpływ składu badanych próbek sześciennych na ich średnią wytrzymałość na ściskanie

Fig. 3. Influence of compositions of the cube samples on their average compressive strength 


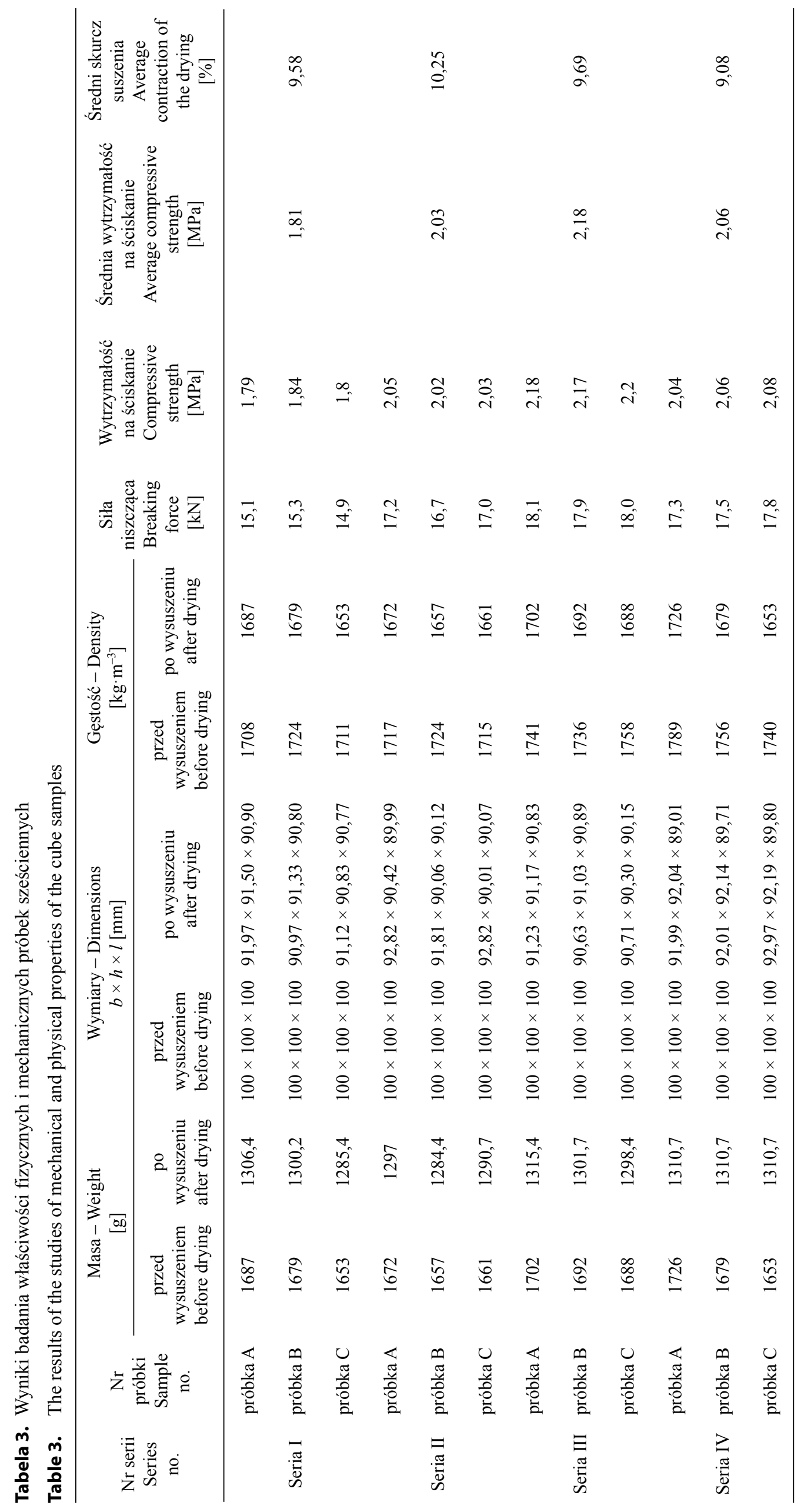




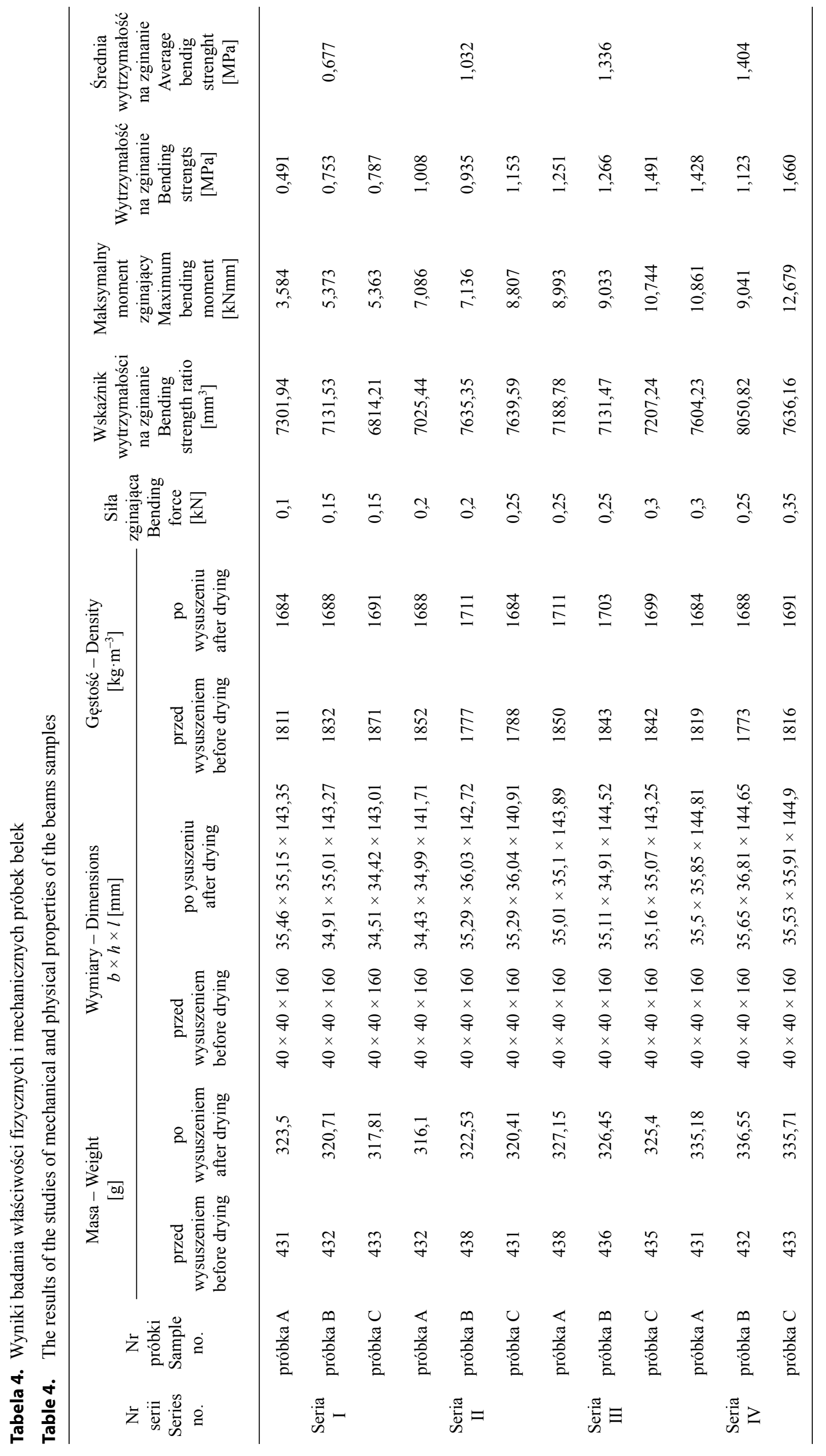


Podobny efekt można zaobserwować w przypadku badań wytrzymałości na zginanie, w których dodatek słomy i piasku wpływa na zwiększanie wytrzymałości badanych próbek. Uzyskano odpowiednio wytrzymałość na zginanie od 0,68 MPa dla próbek serii I, 1,03 dla serii II, 1,34 dla serii III i 1,4 MPa dla próbek serii IV (tab. 4, rys. 4). bez dodatków (seria I - 1,81 MPa, seria II - 2,03 MPa, seria III - 2,18 MPa, seria IV - 2,06 MPa).

4. Pozytywnym zjawiskiem jest zwiększenie wytrzymałości na ściskanie wraz ze wzrostem ilości zastosowanych dodatków do granicznych wartości uzyskanych dla badanych próbek serii III. W przypadku próbek serii IV przyjęta zawartość dodatków wpłynęła na nieznaczne zmniejszenie wytrzymałości na ściskanie.

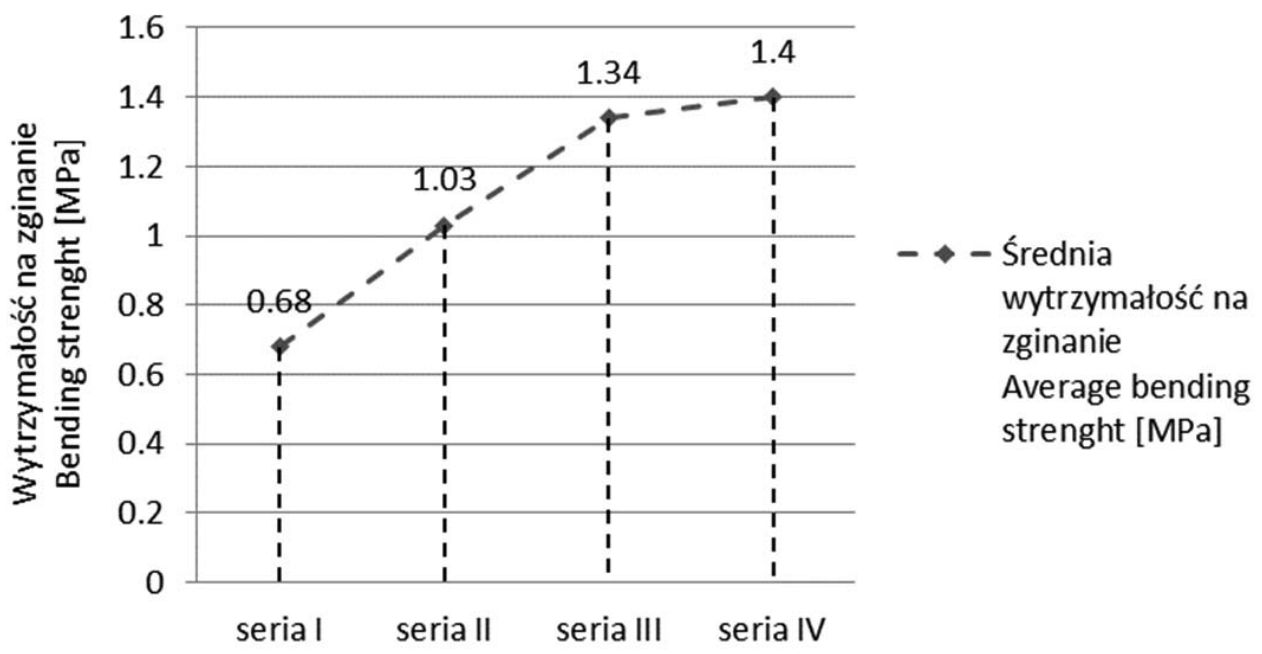

Rys. 4. Wpływ składu badanych próbek belek na ich średnią wytrzymałość na zginanie

Fig. 4. Influence of compositions of the beams samples on their average bending strength

\section{WNIOSKI}

1. Stwierdzono istotny wpływ dodatku słomy i piasku kwarcowego w różnych proporcjach na zmianę gęstości objętościowej. Wraz ze wzrostem udziału tych dodatków obserwuje się stopniowe zwiększanie gęstości objętościowej: seria II $-1673 \mathrm{~kg} \cdot \mathrm{m}^{-3}$, seria III $-1694 \mathrm{~kg} \cdot \mathrm{m}^{-3}$. W przypadku serii IV, gdzie udział słomy wynosił $13 \%$, a piasku $10 \%$, gęstość objętościowa uległa obniżeniu do poziomu $1686 \mathrm{~kg} \cdot \mathrm{m}^{-3}$.

2. Na podstawie uzyskanych wyników badania skurczu można stwierdzić, że stopniowe zwiększanie ilości dodatków do gliny przyczynia się do zmniejszenia skurczu suszenia i pęknięć próbek.

3. Zauważalne jest zwiększenie wytrzymałości kompozytu glinowego wraz ze wzrostem zawartości słomy i piasku kwarcowego w porównaniu do gliny
5. Za optymalny skład kompozytu glinowego można przyjąć, zgodnie z uzyskanymi wynikami badań, serię III, tj. próbki o składzie 58\% gliny, 9\% słomy, 6\% piasku kwarcowego, 27\% wody. Badanie próbek o takim składzie wykazało największą wytrzymałość na ściskanie oraz tylko nieznacznie mniejszą wytrzymałość na zginanie w stosunku do próbek serii IV.

6. Uzyskane wyniki potwierdzają możliwość zastosowania kompozytów glinowych do wznoszenia konstrukcji nośnych budynków. Jednakże każdorazowo należy wykonać badania wytrzymałościowe i cech fizycznych, gdyż każda glina charakteryzuje się odmiennymi właściwościami, zależnie od składu chemicznego i mineralogicznego.

7. Zastosowana $\mathrm{w}$ badaniach glina pochodzącą z wyrobiska Kopalni Węgla Brunatnego „Bełchatów” może być wykorzystana $\mathrm{w}$ budownictwie, co m.in. 
wpłynie na zmniejszenie uciążliwości wyrobiska dla środowiska naturalnego.

\section{PIŚMIENNICTWO}

Backiel-Brzozowska, B. (2014). Budownictwo z gliny i słomy - wstępna ocena wybranych aspektów trwałości. Inżynieria Ekologiczna, 40, 208-216.

BN-62/6738-02. Budownictwo z gliny - Masy gliniane.

Hycnar, E., Jończyk, M. W. i Ratajczak, T. (2017). Popioły lotne i iły beidellitowe z Bełchatowa jako składniki mieszanin samozestalających się. Zeszyty Naukowe Instytutu Gospodarki Surowcami Mineralnymi i Energia PAN, 100, 37-48.

Hyła, M. i Kupiec-Hyła, D. (1994). Domy z lekkiej gliny. Kraków: Zarząd Zespołu Jurajskich parków krajobrazowych w Krakowie.

Kamieniarz, M. (2010). Nowe rozwiązanie z zakresu technologii wznoszenia domów z gliny. Czasopismo Techniczne, 18 (107), 279-280.
Minke, G. (2012). Handbuch Lehmbau: Baustoffkunde, Techniken, Lehmarchitektur. Ökobuch. Freiburg: Verlag Staufen.

Racięcki, Z. (1962). Budynki z gliny. Warszawa: Arkady.

Ratajczak, T. i Hycnar, E. (2017). Kopaliny towarzyszace $w$ złożach węgla brunatnego. T. I. Kraków: Instytut Gospodarki Surowcami Mineralnymi i Energią PAN.

Szuba, B. (2011). Stare technologie w nowej szacie architektury ekologicznej. Journal of Ecology and Health, 15 (2), 55-61.

Wiśniewski, K., Gieniusz, W. i Pawłat-Zawrzykraj, A. (2018). Ekonomiczne aspekty wykorzystania gliny w konstrukcji przegród zewnętrznych budynków w porównaniu z wybranym materiałem tradycyjnym. Acta Scientarum Polonorum Architektura, 17 (1), 25-34.

Wiśniewski, K. i Ziółkowska, M. (2014). Wpływ dodatku popiołu lotnego na właściwości kompozytu glinowo-popiołowego. Acta Scientarum Polonorum Architektura, $12(4), 81-89$.

\title{
ASSESSMENT OF PHYSICAL AND MECHANICAL PROPERTIES OF CLAY COMPOSITE WITH ADDITION OF STRAW FOR USE IN CONSTRUCTION
}

\begin{abstract}
The paper presents the results of the research on selected physical and mechanical properties of the clay composite with the addition of straw and quartz sand. The clay content in the tested samples ranged between $63 \%$ and $53 \%$, straw $5-13 \%$, sand $4-10 \%$. The tests of contraction, density, bending strength and compressive strength of clay composite samples were carried out. The obtained results indicate the positive impact of additives on the tested properties. Along with the increase in the content of straw and quartz sand, the contraction of the drying decreased, the compressive and bending strength increased. The best results were obtained for samples containing $58 \%$ of clay, $9 \%$ of straw, $6 \%$ of sand, and $27 \%$ of water. The obtained test results indicate the suitability of the examined composite as a material for erecting load-bearing structures of buildings.
\end{abstract}

Key words: clay, straw, building materials, contraction, strength 